\title{
Journal of Plant Biology and Crop Research
}

Open Access Publisher

Open Access | Review Article

\section{Aspects of xenobiotics phytoremediation and role of endophytic bacteria and arbuscular mycorrhizal association}

\author{
Qudsia Kanwal' *; Sehar Shad ${ }^{2}$ \\ ${ }^{1}$ Environmental Toxicology Laboratory, University of the Punjab, Pakistan \\ ${ }^{2}$ Department of Zoology, University of the Gujarat, Pakistan
}

\author{
*Corresponding Author (s): Qudsia Kanwal \\ Environmental Toxicology Laboratory, College of Earth \\ and Environmental Sciences, University of the Punjab, \\ Lahore 54590, Pakistan \\ Email: qudsiakanwal18@yahoo.com
}

Received: Jun 01, 2018

Accepted: Aug 24, 2018

Published Online: Aug 30, 2018

Journal: Journal of Plant Biology and Crop Research

Publisher: MedDocs Publishers LLC

Online edition: http://meddocsonline.org/

Copyright: (C) Kanwal Q (2018). This Article is distributed under the terms of Creative Commons Attribution 4.0 International License

Keywords: Phytoremediation; Xenobiotics; Biodegradation; Hyper accumulator; Transgenic plants

\section{Introduction}

Man actions have been producing enormous waste quantities that are being cast off into soil with or without proper treatment. Soil a major factor for human survival as synthetic organic compounds have been continuously adding in it, thus causing environment pollution. Many detrimental organic compounds which have identified by various field and laboratory tests include halogenated aliphatic and aromatic compounds (like biphenyls, anilines and benzenes) and various pesticides $[1,2]$. Briefly the major sources of these organic compounds include solid and waste water residues releases from several industries like paper and pulp, plastic, textile, chemical and agricultural.

\begin{abstract}
Xenobiont entrance in soil and food chain is a major concern of present era. Enhanced legislation, environmental management system and risk control procedures leads to green and clean technologies. Therefore phytoremediation is a best suitable option. The efficacy of phytoremediation techniques depend upon selection of plant, fungal and bacterial partner and situation of contaminated sites. Each type has its own benefit and harms and can be selected by phytoremediation decision tree. Subsequently, naturally and genetically modified bacteria, endophytic bacteria and Arbuscular Mycorrhizal (AM) fungi can be used that have a great capacity to convert and mineralize various organic compounds of both natural and xenobiotics origin. Briefly, recent advances suggest the use of transgenic plants with enhanced cleanup potential. Hence, this review presents the status of phytoremediation technologies with special emphasis on microbial and transgenic plants use.
\end{abstract}

Additionally these industries include enhancement products such as, biocides (i.e. fungicides, algaecides, bactericides), herbicide and pesticides residues, NSAIDs (Non-steroidal antiinflammatory drugs) and pharmaceutical products [3].

Subsequently, these pollutants can be mineralized and broken down by using plants and microorganisms. Natural rate of biodegradation of these organic compounds is controlled by different physicochemical conditions such as $\mathrm{pH}, \mathrm{O}_{2}$ concentration, temperature and salinity. It can also be affected by predation, nutrients accessibility and substrates availability such as dissociation from adsorbed material and solubility [4,5].

Cite this article: Kanwa Q, Shad S. Aspects of xenobiotics phytoremediation and role of endophytic bacteria and arbuscular mycorrhizal association. J Plant Biol Crop Res. 2018; 2: 1007. 
Conversely, this biodegradation method is comparatively slower in view of environmental and public health perspectives. The slow biodegradability can caused by incapability of microorganisms to effectively metabolize the organic pollutants which have unusual properties and structures [6]. These compounds are alien to existing enzyme systems and are called xenobiotics. However, various microbial communities which come into contact with these xenobiotics compounds have the ability to adapt themselves and many microorganisms can completely metabolize these xenobiotics thus can be isolated commercially at a significantly high rate. But there is very little knowledge about molecular events which help these microbial communities to adapt themselves to these chemicals [7].

Phytoremediation is the principal pollution control method particularly for most of organic compounds. Therefore it is one of the most significant parameter affecting the behavior and linked toxicity in terrestrial and aquatic ecosystems [8]. Moreover, this type of biodegradation is dependent on several factors such as temperature, level of acclimation, types and characteristics of microorganisms population, availability of metabolic cofactors (like nutrients and oxygen etc.), growth medium, cellular transport characteristics and chemical partitioning capabilities etc. $[9,10]$. While using the microorganisms designed for the remediation of these compounds, it is essential to keep inoculating these microorganisms and applying nutrients for their survival at adequate level for long period of time [11]. On the contrary, it is possible that the microorganisms which show great efficiency to biodegrade these compounds in laboratory conditions may not be equally effective at real contamination sites $[4,12]$. It is very difficult or almost impossible to control these parameters. Hence, it is often challenging to assess the structure and toxicity of products resulting from biodegradation.

Further, plants have numerous pollutant attenuation mechanisms that are more viable as compared to the chemical and physical treatments used in remediation of contaminated water and land [13-15]. Plants have evolved a broad range of abilities to deal with these environmental toxins due to their nonmigratory nature. They act as solar-driven filtering and pumping systems because of their ability to take up the water soluble contaminants by their roots and translocation of these contaminants by various tissues where they can be sequestered, volatilized (phytovolatilization) or metabolized (phytodegradation), plant microbe contaminant interactions within root zone [rhizospheres) [7,16,17].

The objectives of this review is to throw light on phytoremediation potential on treating contaminated site and to provide a brief view about its types, microorganism's role and future aspects. We emphasize on the need to better transfer phytotechnologies to the business sector so we can explore ways to improve the economic viability of these technologies. Depending on type of remediation, phytoremediation can be categorized into following sub-categories (Table 1).

\section{Rhizodegradation}

Rhizodegradation is the augmentation of degradation that is taking place naturally in soil by influencing plant roots that can leads to the ideal detoxification of these organic contaminants. This process is applied to a large number of organic compounds like petroleum hydrocarbons, chlorinated solvents, pesticides, surfactants, PAHs and polychlorinated biphenyls etc [23]. The root exudates of plants possess few organic compounds that supplies carbon and nitrogen in order to promote the growth along with increased life span of those microorganisms that degrade organic toxins. Furthermore, studies showed that the development of the microorganisms is stimulated by the plant roots as it is known that certain organic compounds like organic acids, amino acids, enzyme, sugars, and complex carbohydrates are released by the plant roots for the development of microorganisms $[24,25]$. Rhizospheric microbial populations help in synthesizing compounds that lowers the stress level in plants, conveying nutrients, shielding against pathogens and degrade pollutants [26]. Consequently, the use of rhizospheric and endophytic microorganisms (bacteria) are able to degrade poisonous organic compounds together with specific plants.

The density of microorganisms in the rhizosphere can be two to four times greater as compared to microbial population in the non-rhizospheric soil, promoting the Polycyclic Hydrocarbons (PAH) degradation in rhizospheric soils [27-29]. Following annual plant growth, the PAH destroy 100 folds microbial colonies in vegetated managements as compared to un-vegetated groups [26]. It was reported that phenanthrene degradation is significantly increased by the addition of root exudates and debris of oat plant [30].

Microbial community in the rhizosphere is reliant on plant age, root type, soil type, and plant species as well as other factors such as exposure history of the plant roots to xenobiotics. In general, the rhizosphere is populated with mostly gram negative microbial community [31]. Carbon dioxide concentration in the rhizosphere is usually more as compared to that in non-vegetated soil, and $\mathrm{pH}$ of rhizosphere soil differs by 1-2 units from that of non vegetated soil. The oxygen concentrations moisture level, redox and osmotic potentials are among the other parameters affected by vegetation. These parameters are additionally influenced by certain characters of specific plant species. The frequent change at the root soil interface, both physical and chemical, produce stable alterations in the soil structure along with microbial environment [17].

Microbial biomass increases in terms of size as an effect of plant microbe communication as compared to those that are found in bulk soils. The rhizosphere effect is usually expressed as the ratio of number of organisms in rhizosphere soil to those in non-rhizosphere soil. This ratio usually ranges from 5-20 but it can be 100 or greater. The increased microbial growth and activity in the region of rhizosphere might be responsible for enhanced metabolic degradation rate of various xenobiotics compounds. Therefore, an intriguing question is whether selection of plants with super modulating roots, propagation of root hairs, or further hereditarily firm property of plant roots would positively influence the microbial degradation rates of specific toxicants in the rhizosphere [32].

\section{Rhizofiltration}

Rhizosphere has been focal point in agricultural research due to its role in crop productivity. It is the area of maximum microbial activity and plant biomass at plant roots-soil interface [33]. Particularly, this zone is under the control of plant roots, hence can be distinguished from bulk soil [34]. Therefore, rhizofiltration is also called as phytofiltration mainly occur in the surface, ground and waste water. In this process the contaminants are removed through the absorption of contaminants into plant roots or their precipitation/adsorption onto plants roots. Subsequently, accumulation of contaminant can occur in roots as well as it can retain in any other part of plant body. However, there is a need to firstly acclimate the plants to the contaminant, as 
such plants cannot be planted directly in situ but it makes this process time consuming and a little tedious. The example of this process includes sunflower which is grown in pools which are radioactively contaminated. Other examples include Indian mustard, tobacco, rye, spinach and corn that are proven to remove heavy metals especially Lead $(\mathrm{Pb})[19,35]$.

\section{Phytodegradation}

It is also known as phytotransformation, a process in which metabolization and degradation of the organic compounds is done in the soil surface, ground water, sediments or sludge's through enzymes produced by the plants. Phytotransformation can be well described by term "green liver modal" because these plants act analogically to human liver while it comes in contact with the xenobiotics [36].

\section{Phytovolatilization}

In this process water soluble contaminants are taken up by means of plants resulting in the discharge of volatile contaminants or the release of volatile degradation products of or volatile form of initially non-volatile toxic compounds [37]. Volatile radionuclides (e.g., ${ }^{3} \mathrm{H}$ ) from soil are extracted by plant and then it is volatized from the leaves. Tritium a radioactive isotope of $\mathrm{H}_{2}$ on decaying it produces helium. It pose serious health hazard when absorbed in body by incorporating in to water body or organic components [38].

Phytovolatilization system can be introduced by high-transpiring phreatophytes with idea to reduce water infiltration into source soil, stabilize the top soil to avoid erosion, runoff and downward sedimentation that hydraulically contain ${ }^{3} \mathrm{H}$ and VOCs that migrate to ground water and continued remediation of the residual VOCs in the plume. The performance of this system depend on ${ }^{3} \mathrm{H}$ concentration in air that is closely monitored $[38,39]$.

\section{Phytohdraulics}

Also known as hydraulic plume control is the degradation of ground water contaminants by using deep-rooted plants which come into contact with them. This technique has been used to recover ground water column of methyl-tert-butyl-ether [40].

\section{Phytostabilization}

It is also known as phytoimmobilization. This method involves the immobilization of water and soil born contaminants by using of plants. The by-products of metabolism of such contaminants can be adhered or integrated into various plant components e.g. lignin therefore, known as phytolignification [40].

\section{Phytoextraction}

Phytoextraction is also called phytoabsorption, phytosequestration and phytoaccumulation, a method in which the contaminants are taken up by plant roots resulting in their accumulation in above ground plant parts, therefore can be harvested and ultimately disposal of plant biomass can reduce the environmental pollution. Phytoextraction is also known as biomining or phytomining.

Phytomining is used to gain plant's extracted hyper accumulated metals from the soils, whether contaminated or naturally containing high levels of these metals. This method is very use- ful especially for the removal of metals from metal contaminating soils and sometimes metal reuse is possible with the help of incorporation of plant incinerations [41]. These processes can directly extract organic as well as metallic constituents from the soils as plant uptake these contaminants and translocation to the central plant biomass. Some hyper accumulating plants that can be used for metal extraction include Brassica juncea, Thlaspi goesingense, Berkeya coddii, Thlaspi caerulescens [36]. This type of metal extraction is environmental friendly but is comparatively slower than anthropogenic method of soil cleanup (Table 2).

\section{Phytoextraction limits}

Phytoextraction best works under specific conditions i.e. underground plant length should be about 3 feet and ground water is within 10 feet of surface $[19,44,45]$. The soil best treated with this method has low to moderate soil contaminant, and the sites with small contamination level and huge volumes of ground water $[46,19]$. Subsequently, $\mathrm{Zn}$ and $\mathrm{Cd}$ soil acidification effect by Phytoextraction was studies and proposed the use of $\left(\mathrm{NH}_{4}\right)_{2} \mathrm{SO}_{4}$ and Phosphorus fertilizers as a soil stabilizer to provide nutrient ( $\mathrm{N}, \mathrm{P}$ and $\mathrm{S}$ ) for higher yield and greater metal bioavailability. Conversely increased soil acidification has negative effects. For instance, the increased solubility of metals increases leaching rate in ground water thus increase environmental risk. Therefore, liming of soil to neutralize soil pH is commonly used [47]. On the other hand, premature liming can increase soil capacity for metal binding thus restricting potential for Phytoextraction. Natural chelators of plants or microbial origin seem more promising than synthetic chemical chelators $[19,48]$ because later have additional toxicity, thus they may increase the uptake of metals but decrease plant growth thus proving to be of limited benefit [19].

\section{Aquatic plants used in bioremediation}

Aquatic plants are chosen to absorb particular nutrient and to remove pathogens, metals and other contaminants from wastewater. Briefly, inorganic pollutants are mainly removed by rhizofiltration, phytostabilization and phytoextraction while organic pollutants are removed by phytodegradation, phytovolatilization and rhizodegradation. For instance, water Lily has a wide ranging root system with fast growth rates, but is sensitive to freezing temperature; it is an ideal plant for water treatment in warm climates. Duckweed (Lemnoideae) and Penny wort ( $\mathrm{Hy}$ drocotyl spp) has greater cold tolerance and has good absorption and up taking of nutrient capacity respectively [49]. Water hyacinth uptake of heavy metal e.g., Lead, Copper, cadmium, Mercury from contaminated water [50]. The commonly used aquatic plants in bioremediation for water bodies are as follow (Table 3).

\section{Latest trends in phytoremediation}

The use of various endophytic bacteria such as Pseudomonas, Azospirillum, Burkholderia and Bacillus is a recent approach to ameliorate detoxification and phytoremediation of contaminants [54]. This review entails the wide range of toxic synthetic organic compounds that are recognized as environmental soil contaminants along with the possible uses of plant associated endophytic and rhizospheric bacteria that are involved in the above mentioned organic compounds. 


\section{Bacterial degradation}

Role of endophytic bacteria in phytoremediation: An endophytic bacterium is a microorganism that inhabits the inner plant tissues, having no negative or infectious sign externally on their host [55-57]. Additionally approximately 300000 plant species that exist today serves as a host to one or more endophytes $[57,58]$. Therefore, moderately hydrophobic pollutants such as benzene, toluene, ethyl benzene and Xylene (BTEX) compounds, chlorinated solvents, nitrotoluene ammunition wastes and excess nutrients $[59,60]$ are recently treated with endophytic bacteria. Phytoremediation of organic xenobiotics involves pulling pollutant by plants into their rhizosphere through the transpiration stream [59,61]; afterward microorganisms facilitated degradation in the rhizosphere or in both [59]. A large number of endophytic bacteria found in plants are reported to be involved in degrading the pollutants of environment. Endophytes from BTEX-contaminated sites found on hybrid poplar trees were isolated, where they showed degradation of toluene and naphthalene along with chlorinated organic herbicide [62-64].

The current review puts light on various benefits of using endophytic bacteria involved in phytoremediation of the contaminated soil while comparing with plants without endophytic bacteria [65]. The likely advantages are, (1) the quantitative expression of bacterial pollutant catabolic genes could be useful in assessing the efficacy of remediation process, (2) manipulation of bacterial catabolic pathway by genetic engineering is way easy as compared to that of a plant, (3) in plant degradation of toxic pollutants by endophytic bacteria thereby dropping the toxic effects on flora and fauna of soil. On the other hand, there are few disadvantages of using bacteria in bioremediation process which includes (1) limitation to shallow contaminants of soil, (2) slower as compared to traditional technologies, (3) seasonally effective when it comes to the choice of a plant, (4) the process is linked with the phytotoxic effects of the contaminants, and (5) there is a possibility that environmental contaminants or their metabolites may enter the food chain when they are not fully detoxified also if the same plants are eaten up by the local fauna [65]. In spite of these disadvantages, it is likely that the bacteria make considerable contribution to the process of bioremediation. One of the recent review claim the chief advantage of endophytic bacteria over rhizospheric bacteria is that the population of rhizospheric bacteria is hard to control and also different strains need to compete which usually results in reduction of desired specie, whereas endophytes naturally populate in the internal plant tissues without encountering the dilemma of competition.

\section{Increased degradation of toxic compounds by bacteria}

Manipulation of bacterial strains by means of biotechnology may lead to the production of certain enzymes that are able to degrade the toxic organic compounds. Rhizospheric as well as endophytic bacteria could be engineered through natural gene transfer or by using recombinant DNA technology to get specific enzymes that efficiently degrades the environmental pollutants. This manipulation of bacteria is thought to be most promising technology for the remediation of contaminated sites.

Host plants that are native to geographical region may act as a source for the isolation of endophytic bacteria. These bacteria can then be genetically engineered, containing specific genes to further improve the degradation by targeting specific contaminants. A genetically engineered endophytic strain (Pseudomonas putidaVM1441, i.e., Pseudomonas putidaVM1441 (pNAH7) isolated from poplar trees was reported to protect the inoculated pea plants from the lethal effects of naphthalene [62]. The same inoculated plants showed up to $40 \%$ higher naphthalene degradation when compared to the uninoculated plants in contaminated soil. It is reported that a genetically engineered endophytic strain of the soil bacterium Burkholderia cepacia G4 increases the inoculated yellow lupine plant tolerance to toluene, and decreases phytovolatilization of toluene from the plant into the atmosphere by $50-70 \%$ in laboratory scale experiments [59] (Table 4).

\section{Fungal degradation}

Role of mycorrhizal fungi in phytoremediation: Conversely, microorganisms forms a symbiotic association with Mycorrhizal fungi and are also involved in phytoremediation as a fundamental soil re-establishment programs [90]. In this respect several studies have shown that ectomycorrhizal and ericoid mycorrhizal fungi plays a significant part in the phytoremediation of metalpolluted sites [91].

\section{Arbuscularmycorrhizal Fungus (AMF)}

The most prominent symbiotic fungus for potential use in phytoremediation is the Arbuscular Mycorrhizal Fungus (AMF) due to its ubiquity in soil environments and it enhances plant tolerance against higher metal concentration in soil [92]. Although a number of reviews have described the contributions of the AMF in metal-contaminated soil [93], there has been no comprehensive review linking in detail the AMF metal tolerance means to its environmental significance.

Arbuscularmycorrhizal Fungi (AMF) are ever-present in soil micro flora, thus comprising a significant useful constituent of the rhizosphere. They form symbiotic associations with roots of $80-90 \%$ land plants in agricultural, natural, and forest ecosystems [94]. Associations like these are also frequently found in aquatic plants under oligotrophic circumstances [95]. AMF symbiosis is 4460 million years old where it is considered as the most extensive type of mycorrhizal relation with plants having true roots, i.e. gymnosperms, pteridophytes and angiosperms [96]. Around 160 fungal taxa of Glomeromycota have been described on the basis of their spore morphology and root infection patterns.

The amount of AMF fungal taxa is possibly higher according to current molecular analyses [97]. AMF may also take part in guarding the roots from heavy metal toxicity by mediating exchanges among metals and plant roots [98]. The peripheral fungal hyphae make use of the larger volumes of nutrients that can't be taken up by the plant roots alone. As a result, AMF is considered as very crucial for the re-vegetation of metal contaminated soils. The effect of chitosan and AM fungus on the accretion of copper, zinc and lead was studied in a soil that is contaminated with copper smelt factory fly ash and it was reported that mycorrhizal fungi showed increased uptake of the metals devoid of any heavy metal toxicity when compared with controls $[99,98]$. In E. splendens AMF or chitosan are not involved in increasing the metal concentrations up to considerable level when taken alone [99]. Therefore, AM fungi have the ability to differentiate their hot host with the help of specific signals that are released by the roots of host plants. In case of host root deficit, the fungi don't make the mycelia and so complete their life cycle. The root exudates of host plant of AMF are well established to stimulate the spore germination along with the early hyphal growth of AMF. Contrast to this, the root exu- 
dates from the non-mycorrhizal host plants like spinach, lupine, sugar beet and mustard are known to decrease the asymbiotic and symbiotic hyphal growths of AMF from spore and root colonization level [100].

Furthermore, decreased root colonization by the AM fungi is considered as a consequence of inhibitory compounds present in the crucifers root exudates that play important part in the manifestation of non-host status of certain plants. It was currently reported that C-glycosyl flavonoids was found in the roots of non-mycorrhizal melon which improves root colonization, suggesting that root colonizing-stimulating compounds in the root exudates play significant role in mycorrhization. Piche and its associates recently reported that the root exudates of nonmycorrhizal cucumber plant stimulates the root colonization, but the root exudates from the nonmycorrhizal as well as the mycorrhizal sides of split root system don't illustrate the same motivating effect and appeared inhibitory to some extent $[101,102]$. These studies suggest that the root exudates found in the mycorrhizal plants are likely to be partially involved in the complete resistance to soil-borne pathogens of fungus. The obligatory biotrophic AMF loses its viability and ability of infection in the absence of their host. Multiple cellular activities take part for the survival of AMF alone that is growing without the host plant [101]. The outside influence and actions of individual AMF spores germinating without appropriate host, effects their survival because of vigorous cellular activities that are occurring in the cytoskeleton of AM fungal hyphae, experiencing the extensive growth arrest and source reallocation. Unlimited presence of AM fungal spores found in soil in the absence of host plants encourage the subsequent increase in the amount of blank AM fungal hyphae, signifying the occurrence of senescence phase in AMF mycelia. However, the dormant AM fungal spores remain viable and are able to rehabilitating the growth in reaction to host plant roots [102].

\section{AMF in heavy metal contaminated soil}

Glomeromycota AMF is a common element of the majority of ecosystems. They work together with $80 \%$ of plant roots and are consider as useful extensions that significantly increase the soil volume for the uptake of nutrients [103]. To make use of AM symbiosis in phytoremediation, it should be considered that how fungus and its symbiotic organization are effected by soil contamination. Spores and pre-symbiotic hyphae are generally sensitive to HM (heavy metal) in the lack of plants. EC50 values (effective concentration reducing hyphal growth to $50 \%$ ) vary with damage, however on the whole negative effects at high HM concentrations are pragmatic [104]. Spores of HM from contaminated as well as uncontaminated soils were taken and their germination along with hyphal growth was checked in vitro accompanied with $\mathrm{Pb}, \mathrm{Zn}$ and $\mathrm{Cd}$. The hyphal growth and germination were repressed by the HM in all cultures. Conversely, spores taken from the contaminated soils were more tolerant to higher concentrations of heavy metals as compared to the spores taken from the pure soil. This natural resistance is possibly because of phenotypic plasticity and not due to genetic changes occurring in spores, since tolerance is lost subsequent to one generation in the shortage of heavy metals [104]. Increased tolerance of fungi to certain heavy metals like $\mathrm{Pb}, \mathrm{Zn}$, $\mathrm{Cu}$ or $\mathrm{Cd}$ has been experiential frequently [105].

Moreover, several studies examine the spore count as well as colonization effectiveness of sludge treated sites revealed that the spores that can tolerate high heavy metal concentration eagerly colonize host roots in spite of the low spore counts
[106]. Even though, it is still need to be studied that either the spore count reduces because of spore forming efficiency or as a result of spore fatality in soil. Estimation of $\mathrm{Cd}, \mathrm{Pb}$ and $\mathrm{Zn}$ effect on symbiotic, presymbiotic as well as fungal life stages of Glomus species revealed that the Glomus intraradices is more tolerant to heavy metals as compared to Glomus etunicatum [107] Therefore, it is suggested that tolerance differs among species depending on their genotype. The rhizospheric region of plant is a vibrant ecosystem of diverse species, comprised of fauna, flora and microorganisms which act collectively in a multiplicity of intricate reactions [108]. These connections are chiefly administered by varied range of phenolics that are originated from the plant roots in concert with host of further chemicals [109]. The functions that are performed by phenolics in the rhizospheric region of plants are called as 'rhizosphere effect' $[110,111]$. The root exudates of plants usually contain ions, water, free $\mathrm{O}_{2}$, mucilage, enzymes, numerous carbon containing primary as well as secondary metabolites and importantly, the plant phenolics. Free phenolics differ from specie to specie including time, space and locality. Their concentration in soil ranges from $0.1-0.6 \%$ within dicotyledonous plants, whereas $2.1-4.4 \%$ in case of monocotyledonous plants [112].

Phenolics carry out redox reactions in the soil and specifically influence the escalation of soil microorganisms which are found in rhizosphere. This influences the enzymatic activity, balance of hormones, phyto-nutrients accessibility and competition among adjoining plants [113-115]. As a consequence of active and continually varying interactions, the array and chemistry of soil is distorted considerably depending on the amount and individuality of phenolics released by various plant species. The specific activities of microorganism species in diverse root locations is determinedly modified and shaped. Furthermore, while phenolics pave through the rhizosphere, they get vault by the organic matter present in the soil and are metabolized by bacterial species present in soil [116].

Microorganisms break down phenolics into such elements that help in the mineralization of nitrogen and progression of humus present in soil [117]. The phenolics are involved in metal chelation that improves the soil porosity, thereby providing the active absorption sites as well as enhancing the mobility and bioavailability of certain elements like calcium, magnesium, potassium etc for plant roots [118]. A number of phenolic metabolites like trans-cinnamic acid, salicylic acid, coumarin, benzoic acid, para hydroxybenzoic acid and syringic acid, are phytotoxic. Such as, the accumulation of phenolics in soil can hold back the seed germination and growth [119]. This outcome is likely to be caused by intrusion of cell division as well as normal functioning of cell enzymes. Phenolics are involved in the inhibition of phosphatase and prolylaminopeptidase implicated in germination of seed [120]. In addition, phenolics have been shown to affect the course mineral uptake by plants [121]. Majority of phenolic root exudates are endowed with chemotactic signals for numerous soil microorganisms which recognize them and shift towards the plant roots in carbon rich rhizospheric region [122]. Depending upon the kind of root-derived chemicals, positive as well as negative pathways began involving the roots, roots and insects, and roots and microbes are present. A variety of organisms are kept away or fascinated to same chemical signal, thereby diverse responses are extracted from special receivers.

Isoflavones from soybean roots, Bradyrhizobium japonicum as well as the pathogenic Phytopthora accurately exemplify chemo-attractant supply for symbiosis [123].The amount and 
activity of microorganisms in root region is greatly increased by root-microbe interactions, leading to the colonization of roots [124]. Normally, the root elongation region present behind the tip is involved in the growth of most important root colonizers which utilize the readily degradable sugars in addition to organic acids.

Conversely, fungi and bacteria usually colonize in the older root regions which contain sloughed cells with lignified cellulose, hemicelluloses and carbon deposit. Grown up community of fungus usually colonize the nutrient rich environments provided by the lately rising lateral roots as well as secondary nongrowing root tips. Colonization of vesicular AMF in response to isoflavonoids as of soybean roots lead to increased phosphorus accomplishment for plant nutrition, greater water associations, which consequently show increased plant growth $[125,126]$. Throughout the shortage of phosphate, plant roots also derive strigolactones. The apocarotenoid molecules are recognized as host-derived signaling compounds at pre-symbiotic stage $[127,128]$. In contrast to various flavonoids which encourage just the hyphal branching in limited figure of host plants, the strigolactones correspond to primary signaling factors for hyphal branching and growth of AMF [129].

Additional optimistic possessions of root colonizers involve the symbiotic relations with epiphytes as well as mycorrhizal fungi, nitrogen fixation by varied classes of Proteobacteria [130], improved biotic and abiotic stress forbearance due to the presence of endophytic microbes [131], along with several advantages by diverse rhizobacteria [132].

\section{Transgenic plants and phytoremediation}

In terms of transgenic plants well established research is present, for instance the over expression of the bacterial mercuric reductase in yellow poplar (Liriodendron tulipifra L.) and eastern cottonwood (Populus deltoids) $[133,134]$. Subsequently three modified merA, merA9 and merA18 constructs were used in these plants and it was found 10 folds higher efficiency for mercury volatilization, $\mathrm{Hg}$ (II) and proembryogenic masses as compared to wild type plants [43]. Conclusively the use of these plant will enhance results (Table 5).

\section{Conclusion}

Anthropogenic activities can boost pollution load in environment, to tackle such situation Phytoremediation is a promising sustainable, viable and inexpensive choice. Subsequently, the accumulation of various pollutants and their other substitute products can result in the formation of a xenobiont. Briefly, these xenobiont can be treated with natural remediation process such as microbial remediation and phytoremediation, with their subtypes as discussed in the present review. Each technique has its own specific way to degrade the xenobiont with some negative effects on the environment because of fragmentation and bioaccumulation. Even though Phytoremediation is slow process with some limitations, but generally it covers wide array of recalcitrant degradation and it considered as an improved choice due to nature of its degradation. Furthermore, new horizons should be discovered like transgenic plants and modified genome bacteria and fungi can give better efficiency. Hence, the main factor driving the implementation of phytoremediation are low costs with significant improvements in site and the potential for ecosystem restoration.

\section{Tables}

Table 1: Brief Outline of Phytoremediation.

\begin{tabular}{|c|c|c|c|c|c|}
\hline $\begin{array}{l}\text { Sr. } \\
\#\end{array}$ & $\begin{array}{l}\text { Phytoremediation } \\
\text { Types }\end{array}$ & Medium & $\begin{array}{c}\text { Contaminant } \\
\text { (General Category) }\end{array}$ & Process Goal & Contaminants (Chemical Categories) \\
\hline 1 & Rhizodegradation & $\begin{array}{c}\text { Soil, Sediments, } \\
\text { Sludge, Ground } \\
\text { Water }\end{array}$ & Organic/Inorganic & $\begin{array}{l}\text { microbial enzymatic degradation } \\
\text { of contaminants in rhizosphere }\end{array}$ & $\begin{array}{l}\text { Biodegradable organics (BTEX, TPH, } \\
\text { PAHs, PCBS, Pesticides) }\end{array}$ \\
\hline 2 & Rhizofiltration & $\begin{array}{l}\text { Wastewater } \\
\text { from Wetlands, } \\
\text { ground water }\end{array}$ & Organic/Inorganic & $\begin{array}{l}\text { Absorption/adsorption and pre- } \\
\text { cipitation on plant root }\end{array}$ & $\begin{array}{c}\text { Metals (Pb, } \mathrm{Cd}, \mathrm{Cu}, \mathrm{Ni} \text {, } \\
\mathrm{Zn}) \text {, Radionuclides, hydrophobic } \\
\text { organics. }\end{array}$ \\
\hline 3 & $\begin{array}{c}\text { Phytotransformation/ } \\
\text { Phytodegradation }\end{array}$ & $\begin{array}{l}\text { Soil, Sediments, } \\
\text { Sludge, Ground } \\
\text { Water, Surface } \\
\text { Water }\end{array}$ & Organics & $\begin{array}{l}\text { Remediation by degradation } \\
\text { by root exudates and cellular } \\
\text { enzymes }\end{array}$ & $\begin{array}{l}\text { Herbicides, chlorinated aliphatics } \\
\text { (e.g. TEC) ammonium } \\
\text { wastes, aromatics } \\
\text { (BTEX), nutrients (nitrates, phos- } \\
\text { phates) }\end{array}$ \\
\hline 4 & Phytovolatilization & $\begin{array}{l}\text { Atmosphere, } \\
\text { Soil, Sediments, } \\
\text { Sludge, Ground } \\
\text { Water }\end{array}$ & Organic/Inorganic & $\begin{array}{l}\text { Remediation by extraction from } \\
\text { media and release in to atmo- } \\
\text { sphere (volatilization) through } \\
\text { stomata }\end{array}$ & Metals(Se, As, Hg), VOCs (i.e. MTBE) \\
\hline 5 & Phytohydraulics & $\begin{array}{l}\text { Ground water, } \\
\text { surface water }\end{array}$ & $\begin{array}{l}\text { Water soluble } \\
\text { organic and Inor- } \\
\text { ganics }\end{array}$ & $\begin{array}{l}\text { Maximum contaminant degrada- } \\
\text { tion or containment by deep } \\
\text { rooted plants }\end{array}$ & Metals (Pb, Cd, Cu, Ni, Zn), \\
\hline 6 & Phytostabilization & $\begin{array}{l}\text { Soil } \\
\text { Sediments, } \\
\text { Sludge, }\end{array}$ & Inorganic & $\begin{array}{l}\text { Containment/ complexation in } \\
\text { soil matrix by root exudates }\end{array}$ & $\begin{array}{c}\text { Metals ( } \mathrm{Pb}, \mathrm{Cd}, \mathrm{Zn}, \mathrm{As}, \\
\mathrm{Cu}, \mathrm{Cr}, \mathrm{Se}, \mathrm{U}), \mathrm{Hydrophobic} \mathrm{organics} \\
\text { that are not biodegradable }\end{array}$ \\
\hline 7 & Phytoextraction & $\begin{array}{l}\text { Soil, Sediments, } \\
\text { Sludge, }\end{array}$ & Inorganic & hyper accumulation and Extration & Metals (Pb, Cd, Cu, Ni, Zn), \\
\hline
\end{tabular}

Source: [18-22] 
Table 2: Different Hyperaccumulator plants with respective metals contaminants.

\begin{tabular}{|c|c|c|}
\hline Hyperaccumulator & Contaminants mainly Metals & Common names \\
\hline Astragalus racemosus & Se, atrazine, nitrates, & Potton wood \\
\hline Berkheya coddi & $\mathrm{Ni}$ & Indian mustard \\
\hline Brassica juncea & $\mathrm{Pb}, \mathrm{Cr}(\mathrm{VI}), \mathrm{Cd}, \mathrm{Cu}, \mathrm{Ni}, \mathrm{Zn}, \mathrm{Sr}, \mathrm{B}$, and Se & Alfalfa, juniper \\
\hline Gysophila spaerocephala & $\mathrm{B}$ & Sunflower \\
\hline Haumaniastrum robertii & $\mathrm{Co}, \mathrm{U}$ & Mulberry \\
\hline Ipomoea alpina & $\mathrm{Cu}$ & Grasses \\
\hline Iberis intermedia & $\mathrm{Ti}$, & $\mathrm{As}$ \\
\hline Pteris vittata & ,Ni, $\mathrm{Zn}, \mathrm{Cd}$ & Duck weed \\
\hline Thlaspi caerulescens & & Alpine pennycress \\
\hline
\end{tabular}

Source: $[18,19,36,42,43]$

Table 3: Various aquatic plants used in phytoremediation.

\begin{tabular}{|c|c|c|}
\hline Aquatic plants & Common names & Metals \\
\hline Eichhornia crassipes & Water hyacinth & Platinum(Pt), Palladium (Pd), Ruthenium (Ru) \\
\hline Lemna minor & Duckweed & $\mathrm{Pb}, \mathrm{Cd}, \mathrm{Cu}$ \\
\hline Azolla pinnata & Water velvet & $\mathrm{Cu}, \mathrm{Cd}, \mathrm{Ni}$ \\
\hline Penny wort & Hydrocotyl spp & $\mathrm{As}, \mathrm{Hg}$ \\
\hline Wedelia trilobata Hitchc & Water zinnia & $\mathrm{Cd}, \mathrm{Ni}$ \\
\hline Polygonum hydropiperoides Michx. & Smartweed & $\mathrm{Cu}, \mathrm{Pb}$ \\
\hline Pistia stratiotes L. & Water lettuce & $\mathrm{Hg}, \mathrm{As}$ and Se \\
\hline Hippuris vulgaris L. & Mare's tail & $\mathrm{B}$ \\
\hline
\end{tabular}

Source: [50-53]

Table 4: Endophytic bacteria and plant associations in various metal/compound phytoremediation studies.

\begin{tabular}{|c|c|c|c|}
\hline Bacteria & Compound/metal & Plant associations & References \\
\hline $\begin{array}{l}\text { Pseudomonas aeruginosa strain R75 } \\
\text { and Pseudomonas savastanoi strain } \\
\text { CB35 }\end{array}$ & $\begin{array}{c}\text { Petroleum hydrocarbons, } \\
\text { Mono- and dichlorinated benzoic acids }\end{array}$ & Elymus dauricus (Wild rye) & {$[57,66]$} \\
\hline $\begin{array}{c}\text { P. putida VM1450 } \\
\text { Methylobacterium populi BJ001 }\end{array}$ & 2,4-D Methane, TNT, RDX, HMX & $\begin{array}{c}\text { Populus (Poplar), Salix } \\
\text { (willow), Populus deltoidesnigra } \\
\text { DN34 (Poplar tissues) }\end{array}$ & {$[63,57)$} \\
\hline Pseudomonas sp & MTBE, BTEX, TCE & $\begin{array}{l}\text { Populus cv. Hazendans and } \\
\text { cv. Hoogvorst }\end{array}$ & {$[62,65,67,57]$} \\
\hline B. серасіа Bu61(ртомВи61) & $\begin{array}{l}\text { Toluene, Mono- and di -chlorinated } \\
\text { PCBs }\end{array}$ & Populus (Poplar) & {$[57,68,67]$} \\
\hline Herbaspirillum sp. $K 1$ & $\mathrm{TCP}, \mathrm{TCB}$ & Triticum (Wheat) & {$[69,57]$} \\
\hline Burkholderia cepacia $G 4$ & VOCS (Volatile organic compounds) and toluene & Lupinus luteus L. Yellow lupine. & {$[59,57]$} \\
\hline Arthrobacter spp. & $\begin{array}{l}\text { Aromatic compounds, including homocyclic } \\
\qquad \text { compounds, such as } \\
\text { hydroxybenzoates, as well as Nheterocycles, } \\
\text { including pyridine and picoline }\end{array}$ & Various & {$[67,70]$} \\
\hline
\end{tabular}




\begin{tabular}{|c|c|c|c|}
\hline $\begin{array}{c}\text { Kluyvera ascorbata SUD165 and } \\
\text { SUD165/26 }\end{array}$ & Nickel ,lead, zinc & $\begin{array}{l}\text { Brassica napus (Canola), Lycoper- } \\
\text { sicon esculentum(tomato), } \\
\text { Brassica juncea (Indian mustard) }\end{array}$ & [71] \\
\hline $\begin{array}{c}\text { Microbacterium arabinogalac- } \\
\text { tanolyticum }\end{array}$ & Nickel & Alyssum murale & [72] \\
\hline Rhizosphere and endophytic bacteria & Nickel, Zinc & $\begin{array}{c}\text { Thlaspi goesingense, Thlaspi } \\
\text { caerulescens (Alpine pennycress) }\end{array}$ & {$[73,74]$} \\
\hline Psuedomonas aspleni & Copper & Canola & {$[75]$} \\
\hline $\begin{array}{l}\text { Variovorax paradoxus, } \\
\text { Rhodoccus sp., Flavobacterium sp }\end{array}$ & Cadmium ,Pesticides and herbicides & Indian mustard & {$[67,76,70]$} \\
\hline P. Putida knp9 & Cadmium, lead & Vigna radiata (Mung bean) & [77] \\
\hline Brevibacillus sp. & Lead & Trifolium pratense (Red clover) & [79] \\
\hline Rhizosphere bacteria & Zinc, nickel cadmium, & Graminaceae (grasses) & \\
\hline $\begin{array}{l}\text { Pseudomonas sp. A4, } \\
\text { Bacillus sp. } 32\end{array}$ & Chromium & Indian mustard & {$[80]$} \\
\hline Pseudomonas fluorescens & Arsenic, Nickel & $\begin{array}{l}\text { Helianthus annuus } \\
\text { (Sunflower), Canola }\end{array}$ & {$[81,82]$} \\
\hline P. putida 06909 & Cadmium & Sunflower & {$[83]$} \\
\hline P. putida UW4, P. putida HS-2 & Nickel & Canola & [84] \\
\hline $\begin{array}{c}\text { P. brassicacearum } A M 3, \text { P. margin- } \\
\text { alis } D p 1\end{array}$ & Cadmium & Pisum sativum (Pea) & [85] \\
\hline Sinorhizobium sp. Pb002 & Lead & Indian mustard & {$[86]$} \\
\hline $\begin{array}{c}\text { Azotobacter chroococcum } \\
H K N-5+\text { B. megaterium HKP-1 + B. } \\
\text { mucilaginosus HKK-1 }\end{array}$ & Zinc, copper, lead, cadmium & Indian mustard & [87] \\
\hline B. subtilis SJ-101 & Nickel & Indian mustard & {$[88]$} \\
\hline $\begin{array}{l}\text { Pseudomonas sp. RJ10, Bacillus sp. } \\
\text { RJ16 }\end{array}$ & Cadmium & Canola & [89] \\
\hline
\end{tabular}

Table 5: Pros and cons of phytoremediation technology.

\begin{tabular}{|c|c|c|c|c|}
\hline $\begin{array}{l}\text { Phytoremediation } \\
\text { techniques }\end{array}$ & & Advantages & & Disadvantages \\
\hline Rhizodegradation & $\begin{array}{l}> \\
>\end{array}$ & $\begin{array}{l}\text { In situ and source contaminant degradation } \\
\text { occurs. } \\
\text { Mineralization of the contaminant can } \\
\text { happen. } \\
\text { Smaller installation and maintenance price }\end{array}$ & $>$ & $\begin{array}{l}\text { The rhizosphere can affect an increase in the initial degra- } \\
\text { dation rate as compared to a nonrhizosphere soil, but the } \\
\text { final extent or degree of degradation might be similar in } \\
\text { both rhizosphere and nonrhizosphere soil. } \\
\text { Substantial time is required for development of extensive } \\
\text { root zone } \\
\text { Additional fertilization may be required because of micro- } \\
\text { bial competition for nutrients }\end{array}$ \\
\hline Rhizofiltration & $>$ & $\begin{array}{l}\text { Both terrestrial and aquatic plants can be } \\
\text { used. } \\
\text { Either in situ (floating rafts on ponds) or ex } \\
\text { situ (an engineered tank system) methods } \\
\text { are used. }\end{array}$ & $>$ & $\begin{array}{l}\text { A well-engineered design is required to control influent } \\
\text { ph, concentration, flow rate, chemical speciation and } \\
\text { interaction with other species for optimal metals uptake. } \\
\text { The terrestrial plants may have to grow in a greenhouse } \\
\text { and then introduced in rhizofiltration system. }\end{array}$ \\
\hline $\begin{array}{l}\text { Phytodegradation/ } \\
\text { Phytotransformation }\end{array}$ & $>$ & $\begin{array}{l}\text { Enzymes of a plant can degrade con- } \\
\text { taminants take place in microorganism free } \\
\text { environment. }\end{array}$ & $>$ & Toxic intermediate or degradation products are formed \\
\hline
\end{tabular}




\begin{tabular}{|c|c|c|c|c|}
\hline Phytovolatilization & $>$ & $\begin{array}{l}\text { Contaminants could be changed to lesstoxic } \\
\text { compounds, released to the atmosphere } \\
\text { can be more effectively degraded such as } \\
\text { by photodegradation. }\end{array}$ & $>$ & $\begin{array}{l}\text { The contaminant or a hazardous metabolite might ac- } \\
\text { cumulate in vegetation and be passed on in later products } \\
\text { such as fruit or lumber. Low levels of metabolites } \\
\text { have been found in plant tissue }\end{array}$ \\
\hline $\begin{array}{l}\text { Phytohydraulics/ hy- } \\
\text { draulic plume control }\end{array}$ & $\begin{array}{l}> \\
>\end{array}$ & $\begin{array}{l}\text { lower costs } \\
\text { Deeper roots will have a greater exposed } \\
\text { volume of soil. }\end{array}$ & $>$ & $\begin{array}{l}\text { Plants water uptake is generally affected by climatic and } \\
\text { seasonal conditions; thus, the rate of water uptake will } \\
\text { not be constant. }\end{array}$ \\
\hline Phytostabilization & $\begin{array}{l}> \\
>\end{array}$ & $\begin{array}{l}\text { It is a cheap and less disruptive method. } \\
\text { Re-plantation boosts environmental } \\
\text { restoration. } \\
\text { Removal of risky substances/biomass and } \\
\text { soil is not required. }\end{array}$ & $>$ & $\begin{array}{l}\text { Soil, vegetation, root zone, root exudates and contami- } \\
\text { nant must be regularly monitored to avoid leaching and } \\
\text { contaminant release, metal uptake and translocation to } \\
\text { aboveground parts. }\end{array}$ \\
\hline & & & $>$ & Phytostabilization is considered to as an interim measure. \\
\hline Phytoextraction & $>$ & $\begin{array}{l}\text { Hyperaccumulator plants can be act as a } \\
\text { resource. e.g.: plant biomass with higher } \\
\text { selenium (Se) concentrations can be used } \\
\text { as animal feed and transported to less } \\
\text { deficient areas }\end{array}$ & $>$ & $\begin{array}{l}\text { These plants have slower growth rate, smaller biomass } \\
\text { and with shallow roots system. } \\
\text { These Metals possibly will have a phytotoxic effect }\end{array}$ \\
\hline
\end{tabular}

Source: $[18,135-138]$

\section{References}

1. Lehrbach PR, McGregor I, Ward JM, Broda P. Molecular relationships between pseudomonas INC P-9 degradative plasmids TOL, NAH, and SAL. Plasmid. 1983; 10: 164-174.

2. van der Meer JR, Roelofsen W, Schraa G, Zehnder AJ. Degradation of low concentrations of dichlorobenzenes and 1, 2, 4-trichlorobenzene by Pseudomonas sp. strain P51 in nonsterile soil columns. FEMS Microbiology Ecology. 1987; 3: 333-341.

3. Bester K, Scholes L, Wahlberg C, McArdell C. Sources and mass flows of xenobiotics in urban water cycles-an overview on current knowledge and data gaps. Water, Air, \& Soil Pollution: Focus. 2008 ; 8: 407-423.

4. Goldstein R, Mallory L, Alexander M. Reasons for possible failure of inoculation to enhance biodegradation. Applied and environmental microbiology. 1985; 50: 977-983.

5. Rijnaarts $\mathrm{HH}$, Bachmann A, Jumelet JC, Zehnder AJ. Effect of desorption and intraparticle mass transfer on the aerobic biomineralization of. alpha.-hexachlorocyclohexane in a contaminated calcareous soil. Environmental science \& technology. 1990; 24: 1349-1354.

6. Alexander M. Biodegradation of chemicals of environmental concern. Science. 1981; 211: 132-138.

7. Abhilash P. Phytoremediation: an innovative technique for ecosystem clean up. Our Earth. 2007; 4: 7-12.

8. Peijnenburg W. Structure-activity relationships for biodegradation: a critical review. Pure and applied chemistry 1994; 66: 1931-1941.

9. Karcher W, Devillers J. Practical applications of quantitative structure-activity relationships (QSAR) in environmental chemistry and toxicology. Springer Science \& Business Media. 1990; 1.

10. Parsons J, Govers H. Quantitative structure-activity relationships for biodegradation. Ecotoxicology and environmental safety 1990; 19: 212-227.

11. Eapen S, Singh S, D'souza S. Advances in development of transgenic plants for remediation of xenobiotic pollutants. Biotechnology Advances. 2007; 25: 442-451.
12. Macek T, Kotrba P, Svatos A, Novakova M, Demnerova K, Mackova $\mathrm{M}$. Novel roles for genetically modified plants in environmental protection. Trends in biotechnology. 2008; 26: 146-152.

13. Glick BR. Phytoremediation: synergistic use of plants and bacteria to clean up the environment. Biotechnology advances. 2003; 21: 383-393.

14. Greenberg B, Huang X, Gurska Y, Gerhardt K, Wang W, Lampi $M$, et al. Successful field tests of a multiprocess phytoremediation system for decontamination of persistent petroleum and organic contaminants. 2006.

15. Huang XD, El-Alawi Y, Gurska J, Glick BR, Greenberg BM. A multiprocess phytoremediation system for decontamination of persistent total petroleum hydrocarbons (TPHs) from soils. Microchemical Journal. 2005; 81: 139-147.

16. Doty SL, Shang TQ, Wilson AM, Tangen J, Westergreen AD, Newman LA, et al. Enhanced metabolism of halogenated hydrocarbons in transgenic plants containing mammalian cytochrome P450 2E1. Proceedings of the National Academy of Sciences. 2000; 97: 6287-6291.

17. Dzantor EK. Phytoremediation: the state of rhizosphere 'engineering' for accelerated rhizodegradation of xenobiotic contaminants. Journal of Chemical Technology and Biotechnology. 2007; 82: 228-232.

18. Adams N, Carroll D, Madalinski K, Rock S, Wilson T, Pivetz B. Introduction to Phytoremediation. National Risk Management Research Laboratory. Office of Research and Development. US Environmental Protection Agency. 2000.

19. Ghosh M, Singh S. A review on phytoremediation of heavy metals and utilization of it's by products. Asian J Energy Environ. 2005; 6: 18.

20. Kumar D, Singh B, Sharma YC. Bioenergy and Phytoremediation Potential of Millettia pinnata. Phytoremediation Potential of Bioenergy Plants. Springer. 2017; 169-188.

21. Ross SM. Toxic metals in soil-plant systems: John Wiley and Sons Ltd. 1994.

22. Tangahu BV, Sheikh Abdullah SR, Basri $H$, Idris $M$, Anuar $N$, Mukhlisin M. A Review on heavy metals ( $\mathrm{As}, \mathrm{Pb}$, and $\mathrm{Hg}$ ) uptake 
by plants through phytoremediation. International Journal of Chemical Engineering. 2011.

23. Rentz JA, Alvarez PJ, Schnoor JL. Benzo [a] pyrene co-metabolism in the presence of plant root extracts and exudates: implications for phytoremediation. Environmental pollution. 2005; 136: 477484.

24. Shim H, Chauhan S, Ryoo D, Bowers K, Thomas SM, Burken JG, et al. Rhizosphere competitiveness of trichloroethylene-degrading, poplar-colonizing recombinant bacteria. Applied and environmental microbiology. 2000; 66: 4673-4678.

25. Singer AC, Crowley DE, Thompson IP. Secondary plant metabolites in phytoremediation and biotransformation. TRENDS in Biotechnology. 2003; 21: 123-130.

26. Gerhardt KE, Huang XD, Glick BR, Greenberg BM. Phytoremediation and rhizoremediation of organic soil contaminants: potential and challenges. Plant Science. 2009; 176: 20-30.

27. Alkorta I, Garbisu C. Phytoremediation of organic contaminants in soils. Bioresource Technology. 2001; 79: 273-276.

28. Anderson T, Kruger E, Coats J. Enhanced degradation of a mixture of three herbicides in the rhizosphere of a herbicide-tolerant plant. Chemosphere. 1994; 28: 1551-1557.

29. Sheng-you X, Ying-xu C, Qi L, Wei-xiang W, Sheng-guo X, Chaofeng $S$. Uptake and accumulation of phenanthrene and pyrene in spiked soils by Ryegrass (Lolium perenne L). Journal of Environmental Sciences. 17: 817-822.

30. Miya RK, Firestone MK. Enhanced phenanthrene biodegradation in soil by slender oat root exudates and root debris. Journal of Environmental Quality. 2001; 30: 1911-1918.

31. Atlas RM, Bartha R. Microbial ecology: fundamentals and applications. 1986.

32. Kidd P, Prieto-Fernández A, Monterroso C, Acea M. Rhizosphere microbial community and hexachlorocyclohexane degradative potential in contrasting plant species. Plant and soil. 2008; 302: 233-247.

33. Curl E, Truelove B. The Rhizosphere Springer-Verlag, Berlin. Google Scholar. 1986; 288.

34. Anderson TA, Guthrie EA, Walton BT. Bioremediation in the rhizosphere. Environmental Science \& Technology. 1993; 27: 2630-2636.

35. Raskin I, Ensley BD. Phytoremediation of toxic metals: John Wiley and Sons. 2000.

36. Bruce E. Phytoremediation of contaminated soil and groundwater at hazardous waste sizes. EPA. 2001; 540: 01-500.

37. Mueller B, Rock S, Gowswami D, Ensley D. Phytoremediation decision tree. Prepared by-Interstate Technology and Regulatory Cooperation Work Group. 1999: 1-36.

38. Dushenkov S. Trends in phytoremediation of radionuclides. Plant and soil. 2003; 249: 167-175.

39. Negri MC, Hinchman RR, Wozniak JB. Capturing a mixed contaminant plume: tritium phytoevaporation at Argonne National Laboratory's area 319. Phytoremediation: State of the Science Conf., Boston, MA. 2000; 1-2.

40. Saharan B, Nehra V. Plant growth promoting rhizobacteria: a critical review. Life Sci Med Res. 2011; 21: 30.

41. Shukla KP, Singh NK, Sharma S. Bioremediation: developments, current practices and perspectives. Genet Eng Biotechnol J. 2010; 3: 1-20.
42. Blaylock MJ, Salt DE, Dushenkov S, Zakharova O, Gussman C, Kapulnik $\mathrm{Y}$, et al. Enhanced accumulation of $\mathrm{Pb}$ in Indian mustard by soil-applied chelating agents. Environmental Science \& Technology. 1997; 31: 860-865.

43. Cherian S, Oliveira MM. Transgenic plants in phytoremediation: recent advances and new possibilities. Environmental science \& technology. 2005; 39: 9377-9390.

44. Kruger EL, Anderson TA, Coats JR. Phytoremediation of soil and water contaminants: ACS Publications. 1997.

45. Raskin I, Kumar PN, Dushenkov S, Salt DE. Bioconcentration of heavy metals by plants. Current Opinion in biotechnology 1994; 5: $285-290$.

46. Center A. Phytoremediation: a novel strategy for the removal of toxic metals from the environment using plants. Biotechnology 1995; 13: 468-474.

47. Baker A, McGrath S, Reeves R, Smith J, Terry N, Bañuelos G. Phytoremediation of contaminated soil and water. Phytoremediation of contaminated soil and water. 2000.

48. Rauser WE. Structure and function of metal chelators produced by plants. Cell biochemistry and biophysics. 1999; 31: 19-48.

49. Salt DE, Pickering IJ, Prince RC, Gleba D, Dushenkov S, Smith $\mathrm{RD}$, et al. Metal accumulation by aquacultured seedlings of Indian mustard. Environmental science \& technology. 1997; 31: 16361644.

50. Farago M, Parsons P. The effects of various platinum metal species on the water plant Eichhornia crassipes (MART). Solms. Chemical Speciation \& Bioavailability. 1994; 6: 1-12.

51. Fitz WJ, Wenzel WW, Zhang H, Nurmi J, Štipek K, Fischerova Z, et al. Rhizosphere characteristics of the arsenic hyperaccumulator Pteris vittata L. and monitoring of phytoremoval efficiency. Environmental science \& technology. 2003; 37: 5008-5014.

52. Qian JH, Zayed A, Zhu YL, Yu M, Terry N. Phytoaccumulation of trace elements by wetland plants: III. Uptake and accumulation of ten trace elements by twelve plant species. Journal of Environmental Quality. 1999; 28: 1448-1455.

53. Salt DE, Pickering IJ, Prince RC, Gleba D, Dushenkov S, Smith $\mathrm{RD}$, et al. Metal accumulation by aquacultured seedlings of Indian mustard. Environmental science \& technology. 1997; 31: 16361644.

54. Vishnoi SR, Srivastava P. Phytoremediation-green for environmental clean. Proceedings of Taal2007: the 12th World lake conference. 2007; 1016: 1021.

55. Hallmann J, Berg G, Schulz B. Isolation procedures for endophytic microorganisms. Microbial root endophytes. Springer. 2006; 299-319.

56. Holliday P. A dictionary of plant pathology: Cambridge University Press. 1989.

57. Ryan RP, Germaine K, Franks A, Ryan DJ, Dowling DN. Bacterial endophytes: recent developments and applications. FEMS microbiology letters. 2008; 278: 1-9.

58. Strobel G, Daisy B, Castillo U, Harper J. Natural products from endophytic microorganisms. Journal of Natural products. 2004; 67: 257-268.

59. Barac T, Taghavi S, Borremans B, Provoost A, Oeyen L, Colpaert $J V$, et al. Engineered endophytic bacteria improve phytoremediation of water-soluble, volatile, organic pollutants. Nature biotechnology 2004; 22: 583-588.

60. Schnoor JL, Light LA, McCutcheon SC, Wolfe NL, Carreia LH. Phy- 
toremediation of organic and nutrient contaminants. Environmental science \& technology. 1995; 29: 318A-323A.

61. Harvey PJ, Campanella BF, Castro PM, Harms H, Lichtfouse E, Schäffner AR, et al. Phytoremediation of polyaromatic hydrocarbons, anilines and phenols. Environmental Science and Pollution Research. 2002; 9: 29-47.

62. Germaine K, Keogh E, Garcia-Cabellos G, Borremans B, van der Lelie D, Barac T, et al. Colonisation of poplar trees by gfp expressing bacterial endophytes. FEMS Microbiology Ecology. 2004; 48: 109118.

63. Germaine KJ, Liu X, Cabellos GG, Hogan JP, Ryan D, Dowling DN. Bacterial endophyte-enhanced phytoremediation of the organochlorine herbicide 2, 4-dichlorophenoxyacetic acid. FEMS microbiology ecology. 2006; 57: 302-310.

64. Lodewyckx C, Vangronsveld J, Porteous F, Moore ER, Taghavi S, Mezgeay $M$, et al. Endophytic bacteria and their potential applications. Critical Reviews in Plant Sciences. 2002; 21: 583-606.

65. Moore FP, Barac T, Borremans B, Oeyen L, Vangronsveld J, Van der Lelie $D$, et al. Endophytic bacterial diversity in poplar trees growing on a BTEX-contaminated site: the characterisation of isolates with potential to enhance phytoremediation. Systematic and applied microbiology. 2006; 29: 539-556.

66. Siciliano S, Goldie H, Germida J. Enzymatic activity in root exudates of Dahurian wild rye (Elymus dauricus) that degrades 2-chlorobenzoic acid. Journal of agricultural and food chemistry. 1998; 46: 5-7.

67. Rockne KJ, Reddy KR. Bioremediation of contaminated sites. Invited Theme Paper, International eConference on Modern Trends in Foundation Engineering: Geotechnical Challenges and Solutions, Indian Institute of Technology, Madras, India. 2003.

68. Taghavi S, Barac T, Greenberg B, Borremans B, Vangronsveld J, van der Lelie D. Horizontal gene transfer to endogenous endophytic bacteria from poplar improves phytoremediation of toluene. Applied and Environmental Microbiology. 2005; 71: 85008505.

69. Männistö MK, Tiirola MA, Puhakka JA. Degradation of 2, 3, 4, 6-tetrachlorophenol at low temperature and low dioxygen concentrations by phylogenetically different groundwater and bioreactor bacteria. Biodegradation. 2001; 12: 291-301.

70. O'loughlin EJ, Sims GK, Traina SJ. Biodegradation of 2-methyl, 2-ethyl, and 2-hydroxypyridine by an Arthrobacter sp. isolated from subsurface sediment. Biodegradation. 1999; 10: 93-104.

71. Burd GI, Dixon DG, Glick BR. Plant growth-promoting bacteria that decrease heavy metal toxicity in plants. Canadian journal of microbiology. 2000; 46: 237-245.

72. Abou-Shanab R, Angle J, Delorme T, Chaney R, Van Berkum P, Moawad $\mathrm{H}$, et al. Rhizobacterial effects on nickel extraction from soil and uptake by Alyssum murale. New Phytologist. 2003; 158: 219-224.

73. Idris R, Trifonova R, Puschenreiter M, Wenzel WW, Sessitsch A. Bacterial communities associated with flowering plants of the Ni hyperaccumulator Thlaspi goesingense. Applied and Environmental Microbiology. 2004; 70: 2667-2677.

74. Whiting SN, de Souza MP, Terry N. Rhizosphere bacteria mobilize Zn for hyperaccumulation by Thlaspi caerulescens. Environmental Science \& Technology. 2001; 35: 3144-3150.

75. Reed ML, Glick BR. Growth of canola (Brassica napus) in the presence of plant growth-promoting bacteria and either copper or polycyclic aromatic hydrocarbons. Canadian Journal of Microbiology. 2005; 51: 1061-1069.
76. Belimov A, Hontzeas N, Safronova V, Demchinskaya S, Piluzza G, Bullitta $S$, et al. Cadmium-tolerant plant growth-promoting bacteria associated with the roots of Indian mustard (Brassica juncea L. Czern.). Soil Biology and Biochemistry. 2005; 37: 241250.

77. Tripathi M, Munot HP, Shouche Y, Meyer JM, Goel R. Isolation and functional characterization of siderophore-producing leadand cadmium-resistant Pseudomonas putida KNP9. Current microbiology. 2005; 50: 233-237.

78. Nie L, Shah S, Rashid A, Burd GI, Dixon DG, Glick BR. Phytoremediation of arsenate contaminated soil by transgenic canola and the plant growth-promoting bacterium Enterobacter cloacae CAL2. Plant Physiology and Biochemistry. 2002; 40: 355-361.

79. Vivas A, Azcón R, Biró B, Barea J, Ruiz-Lozano J. Influence of bacterial strains isolated from lead-polluted soil and their interactions with arbuscular mycorrhizae on the growth of Trifolium pratense L. under lead toxicity. Canadian journal of microbiology. 2003; 49: 577-588.

80. Rajkumar M, Vara Prasad MN, Freitas H, Ae N. Biotechnological applications of serpentine soil bacteria for phytoremediation of trace metals. Critical reviews in biotechnology. 2009; 29: 120130.

81. Ashour EH, El-Mergawi R, Radwan S. Efficacy of pseudomonas to phytoremediate nickel by canola (Brassica napus L). 2006.

82. Shilev S, Fernández A, Benlloch M, Sancho E. Sunflower growth and tolerance to arsenic is increased by the rhizospheric bacteria Pseudomonas fluorescens. Phytoremediation of metal-contaminated soils. 2006: 315-318.

83. Wu CH, Wood TK, Mulchandani A, Chen W. Engineering plantmicrobe symbiosis for rhizoremediation of heavy metals. Applied and environmental microbiology. 2006a; 72: 1129-1134.

84. Farwell AJ, Vesely S, Nero V, Rodriguez H, Shah S, Dixon DG, et al. The use of transgenic canola (Brassica napus) and plant growthpromoting bacteria to enhance plant biomass at a nickel-contaminated field site. Plant and Soil. 2006; 288: 309-318.

85. Safronova VI, Stepanok VV, Engqvist GL, Alekseyev YV, Belimov AA. Root-associated bacteria containing 1-aminocyclopropane1-carboxylate deaminase improve growth and nutrient uptake by pea genotypes cultivated in cadmium supplemented soil. Biology and Fertility of Soils. 2006; 42: 267272.

86. Di Gregorio S, Barbafieri M, Lampis S, Sanangelantoni AM, Tassi E, Vallini G. Combined application of Triton X-100 and Sinorhizobium sp. Pb002 inoculum for the improvement of lead phytoextraction by Brassica juncea in EDTA amended soil. Chemosphere. 2006; 63: 293-299.

87. Wu S, Cheung K, Luo Y, Wong M. Effects of inoculation of plant growth-promoting rhizobacteria on metal uptake by Brassica juncea. Environmental Pollution. 2006b; 140: 124-135.

88. Zaidi S, Usmani S, Singh BR, Musarrat J. Significance of Bacillus subtilis strain SJ-101 as a bioinoculant for concurrent plant growth promotion and nickel accumulation in Brassica juncea. Chemosphere. 2006; 64: 991-997.

89. Sheng $X$, Gong J. Increased degradation of phenanthrene in soil by Pseudomonas sp. GF3 in the presence of wheat. Soil Biology and Biochemistry. 2006; 38: 2587-2592.

90. Haselwandter K, Bowen GD. Mycorrhizal relations in trees for agroforestry and land rehabilitation. Forest Ecology and Management. 1996; 81: 1-17.

91. Agerer R. Exploration types of ectomycorrhizae. Mycorrhiza. 2001; 11: 107-114 
92. Hildebrandt $\mathrm{U}$, Kaldorf $\mathrm{M}$, Bothe $\mathrm{H}$. The zinc violet and its colonization by arbuscular mycorrhizal fungi. Journal of Plant Physiology. 1999; 154: 709-717.

93. Hildebrandt $\mathrm{U}$, Regvar M, Bothe H. Arbuscular mycorrhiza and heavy metal tolerance. Phytochemistry. 2007; 68: 139-146.

94. Brundrett MC. Coevolution of roots and mycorrhizas of land plants. New phytologist. 2002; 154: 275-304.

95. Khan A. Mycotrophy and its significance in wetland ecology and wetland management. Developments in ecosystems. 2004; 1: 95-114.

96. Read D, Duckett J, Francis R, Ligrone R, Russell A. Symbiotic fungal associations in 'lower'land plants. Philosophical Transactions of the Royal Society of London B: Biological Sciences. 2000; 355: 815831

97. Daniell T, Husband R, Fitter A, Young J. Molecular diversity of arbuscular mycorrhizal fungi colonising arable crops. FEMS Microbiology Ecology. 2001; 36: 203-209.

98. Smith S. Read DJ. Mycorrhizal symbiosis. 1997: 4-160.

99. Oba H, Tawaraya K, Wagatsuma T. Inhibition of pre-symbiotic hyphal growth of arbuscular mycorrhizal fungus Gigaspora margarita by root exudates of Lupinus spp. Soil science and plant nutrition. 2002; 48: 117-120.

100. Nagahashi G, Douds DD. Partial separation of root exudate components and their effects upon the growth of germinated spores of AM fungi** Mention of a brand name or company name does not constitute an endorsement by the US Department of Agriculture. Mycological Research. 2000; 104: 1453-1464.

101. Logi C, Sbrana C, Giovannetti M. Cellular events involved in survival of individual arbuscular mycorrhizal symbionts growing in the absence of the host. Applied and Environmental Microbiology. 1998; 64: 3473-3479.

102. Vierheilig $H$, Coughlan AP, Wyss $U$, Piché $Y$. Ink and vinegar, a simple staining technique for arbuscularmycorrhizal fungi. Applied and environmental microbiology. 1998; 64: 5004-5007.

103. Harrison MJ. Molecular and cellular aspects of the arbuscular mycorrhizal symbiosis. Annual review of plant biology. 1999; 50 361-389.

104. Göhre V, Paszkowski U. Contribution of the arbuscular mycorrhizal symbiosis to heavy metal phytoremediation. Planta. 2006; 223: 1115-1122.

105. Gaur A, Adholeya A. Prospects of arbuscular mycorrhizal fungi in phytoremediation of heavy metal contaminated soils. Curr Sci. 2004; 86: 528-534.

106. Del Val C, Barea J, Azcon-Aguilar C. Diversity of arbuscular mycorrhizal fungus populations in heavymetal-contaminated soils. Applied and environmental microbiology. 1999; 65: 718-723.

107. Pawlowska TE, Charvat I. Heavy-metal stress and developmental patterns of arbuscular mycorrhizal fungi. Applied and Environmental Microbiology. 2004; 70: 6643-6649.

108. Whipps JM. Microbial interactions and biocontrol in the rhizosphere. Journal of experimental Botany. 2001; 52: 487-511.

109. Dakora F, Phillips D. Diverse functions of isoflavonoids in legumes transcend anti-microbial definitions of phytoalexins. Physiological and Molecular Plant Pathology. 1996; 49: 1-20.

110. Dakora FD. Defining new roles for plant and rhizobial molecules in sole and mixed plant cultures involving symbiotic legumes. New Phytologist. 2003; 158: 39-49.
111. Gregory P. Roots, rhizosphere and soil: the route to a better understanding of soil science? European Journal of Soil Science. 2006; 57: 2-12.

112. Hartley RD, Harris PJ. Phenolic constituents of the cell walls of dicotyledons. Biochemical Systematics and Ecology. 1981; 9: 189-203.

113. Bejan A, Kraus AD. Heat transfer handbook. John Wiley \& Sons. 2003; 1.

114. Hättenschwiler S, Vitousek PM. The role of polyphenols in terrestrial ecosystem nutrient cycling. Trends in ecology \& evolution. 2000; 15: 238-243.

115. Northup RR, Dahlgren RA, McColl JG. Polyphenols as regulators of plant-litter-soil interactions in northern California's pygmy forest: a positive feedback? Biogeochemistry. 1998; 42: 189-220.

116. Kefeli VI, Kalevitch MV, Borsari B. Phenolic cycle in plants and environment. J Cell Mol Biol. 2003; 2: 1318.

117. Hepper CT, Halvorson JJ, Duncan ST, Gregory AJ, Dunn WR, Spindler KP. The Efficacy and Duration of Intra-articular Corticosteroid Injection for Knee Osteoarthritis: A Systematic Review of Level I Studies. Journal of the American Academy of Orthopaedic Surgeons. 2009; 17: 638-646.

118. Seneviratne G, Jayasinghearachchi H. Mycelial colonization by bradyrhizobia and azorhizobia. Journal of biosciences. 2003; 28: 243-247.

119. Baleroni C, Ferrarese M, Souza N, Ferrarese-Filho O. Lipid accumulation during canola seed germination in response to cinnamic acid derivatives. Biologia Plantarum. 2000; 43: 313-316.

120. Kadowaki MK, Simão RdCG, Da Conceição Silva J, Osaku C, Guimaraes L. Biotechnological advances in fungal invertases. Fungal Enzymes CRC Press Taylor \& Francis Group, New York. 2013: 1-30.

121. Lodhi M, Bilal R, Malik K. Allelopathy in agroecosystems: wheat phytotoxicity and its possible roles in crop rotation. Journal of Chemical Ecology. 1987; 13: 1881-1891.

122. Taylor LP, Grotewold E. Flavonoids as developmental regulators. Current opinion in plant biology. 2005; 8: 317-323.

123. Morris MR. Female preference for trait symmetry in addition to trait size in swordtail fish. Proceedings of the Royal Society of London B: Biological Sciences. 1998; 265: 907-907.

124. Bais HP, Park SW, Weir TL, Callaway RM, Vivanco JM. How plants communicate using the underground information superhighway. Trends in plant science. 2004; 9: 26-32.

125. Bagayoko M, Buerkert A, Lung G, Bationo A, Römheld V. Cereal/ legume rotation effects on cereal growth in Sudano-Sahelian West Africa: soil mineral nitrogen, mycorrhizae and nematodes. Plant and soil. 2000; 218: 103-116.

126. Siqueira J, Safir G, Nair M. Stimulation of vesicular-arbuscular mycorrhiza formation and growth of white clover by flavonoid compounds. New Phytologist. 1991; 118: 87-93.

127. Akiyama K, Matsuzaki Ki, Hayashi H. Plant sesquiterpenes induce hyphal branching in arbuscular mycorrhizal fungi. Nature. 2005; 435: 824-827.

128. Akiyama T. Stronger brønsted acids. Chemical Reviews. 2007; 107: 5744-5758.

129. Soto MJ, Fernández-Aparicio M, Castellanos-Morales V, GarcíaGarrido JM, Ocampo JA, Delgado MJ, et al. First indications for the involvement of strigolactones on nodule formation in alfalfa (Medicago sativa). Soil Biology and Biochemistry. 2010; 42: 383- 
385.

130. Bogomolnaia A, Moulin H. A new solution to the random assignment problem. Journal of Economic theory. 2001; 100: 295328.

131. Schardl CL, Leuchtmann A, Spiering MJ. Symbioses of grasses with seedborne fungal endophytes. Annu Rev Plant Biol. 2004; 55: 315-340.

132. Gray E, Smith D. Intracellular and extracellular PGPR: commonalities and distinctions in the plant- bacterium signaling processes. Soil Biology and Biochemistry. 2005; 37: 395-412.

133. Che D, Meagher RB, Heaton AC, Lima A, Rugh CL, Merkle SA. Expression of mercuric ion reductase in Eastern cottonwood (Populus deltoides) confers mercuric ion reduction and resistance. Plant Biotechnology Journal. 2003; 1: 311-319.

134. Rugh CL, Senecoff JF, Meagher RB, Merkle SA. Development of Transgenic yellow poplar for mercury phytoremediation. Nature biotechnology. 1998; 16: 925-928.

135. Banuelos G, Ajwa H, Mackey B, Wu L, Cook C, Akohoue S, et al. Evaluation of different plant species used for phytoremediation of high soil selenium. Journal of Environmental Quality. 1997; 26: 639-646.

136. Komossa D, Langebartels C, Sandermann Jr H. Metabolic processes for organic chemicals in plants. Plant Contamination: Modeling and Simulation of Organic Chemical Processes. 1995: 69-103.

137. Kumar PN, Dushenkov V, Motto H, Raskin I. Phytoextraction: the use of plants to remove heavy metals from soils. Environmental science \& technology. 1995; 29: 1232-1238.

138. Newman LA, Strand S, Domroes D, Duffy J, Ekuan G, Karscig G, et al. Abstract: Removal of trichloroethylene from a simulated aquifer using poplar. Fourth Annual In Situ an On-Site Bioremediation Symposium. New Orleans. 1997. 